Please refer to the published version when citing:

Maxim, C. (2016) Sustainable Tourism Implementation in Urban Areas: A Case Study of London. Journal of Sustainable Tourism, DOI: 10.1080/09669582.2015.1115511.

\title{
Sustainable Tourism Implementation in Urban Areas: A Case Study of London
}

\begin{abstract}
Sustainable tourism is a concept widely embraced by managers and planners of tourist destinations. However, it has received little attention in the context of urban tourism, an area of research that has until recently been largely neglected by academics. This paper contributes to the body of knowledge on sustainable tourism implementation in large cities, by using London as an exploratory case study. Through the collection and analysis of both primary and secondary data (online survey, semi-structured interviews and document analysis), it seeks to explore whether local authorities have implemented policies towards sustainable tourism in the capital. The findings indicate that although the concept of sustainable tourism is perceived as important by policy makers, only a few local authorities in London promote its principles in their policy documents and even fewer have initiatives to put them in practice. Most of these initiatives are isolated activities which address limited aspects of sustainable tourism. The paper concludes that despite some progress made to date, in the current economic climate, growth and development remain the main objectives of governments and local authorities, while social and environmental issues are often left behind.
\end{abstract}

Keywords: sustainable tourism; urban tourism; large cities; local government; London

\section{Introduction}

Sustainable development has become an important objective of the policy agenda for 
governments (Ruhanen, 2008) and a key principle underpinning the planning process in the UK (DCLG, 2006a). Consequently, sustainable tourism is a concept widely embraced by policy makers from both public and private organisations, at all levels of governance (Hall, 2011). Although a relatively new concept that academics have started to research only two decades ago (Buckley, 2012) and despite its criticisms (Sharpley, 2009), sustainable tourism is one of the key areas of study within tourism (Connell \& Page, 2008; Ruhanen, Weiler, Moyle, \& McLennan, 2015). For the purpose of this paper, sustainable tourism is tourism which makes "optimal use of environmental resources" and takes into account the impact of the current and future tourism activities, while also addressing the needs of the tourists, host community, industry and the environment (UNEP \& WTO, 2005, p.11).

Mirroring the arguments on sustainable development implementation (Butler, 2013; Robinson, 2004), Sharpley (2009) points out that the extent to which sustainable tourism policies have been translated into practice is debatable. Liburd and Edwards (2010) also argue that despite the attention lately received by this concept, there are "still many gaps in our understanding of the sustainable development of tourism" (p. 230), particularly when it comes to its implementation. This view is further supported by Farsari, Butler, and Szivas (2011), who look at the complexity in tourism policies and call for future research to focus on the implementation aspects of sustainable tourism. Putting such policies in practice is considered more complex than in the case of other industries due to the conflicting interests between the main tourism stakeholders (Muangasame \& McKercher, 2015; Waligo, Clarke, \& Hawkins, 2013), and sometimes between the government's various structural roles (Krutwaysho \& Bramwell, 2010). Yet, "implementation issues are essential areas of concern if sustainable tourism is to move toward becoming a reality" (Bramwell \& Lane, 2014, p.6). 
This research contributes to the current limited knowledge on sustainable tourism implementation in large cities, destinations that receive "the greatest volume of tourists" (Miller, Merrilees, \& Coghlan, 2015, p.26). Using London as a case study, this paper explores whether local authorities integrate sustainable tourism principles in their policy documents and promote any initiatives to implement them in practice. After highlighting the importance of sustainable tourism and identifying the gap in our understanding of this concept in an urban context, this paper discusses the case study particularities and the methodology adopted. It then presents the findings, together with their implications for sustainable tourism development in large cities.

\section{Literature review}

"The merits of any sustainability policy lie in the ability to implement it in an effective manner." (Muangasame \& McKercher, 2015, p.498)

\section{Sustainable tourism and cities}

The concept of sustainability has received little attention in urban tourism research when compared to studies on other forms of tourism (Law, 2002; Miller et al., 2015; Timur \& Getz, 2008). Even though urban tourism is considered one of the earliest forms of tourism which re-emerged in the 1980s due to a shift in tourist interest towards heritage and culture (European Communities, 2000), this phenomenon has until recently been largely neglected by academics studying tourism (Ashworth, 1989; Ashworth \& Page, 2011; Law, 2002). The most influential study that ignited the interest in urban tourism research is considered to be the work of Ashworth (1989) "Urban Tourism: An Imbalance in Attention". Twenty years later, Ashworth and Page (2011) note some progress towards understanding this field of study, but point out that more research is 
needed to better understand the development of tourism in cities.

There are indeed few studies, most of them over ten years old, which specifically address the topic of sustainable tourism in cities. Barke and Newton (1995) were among the first to highlight that the concept of sustainable tourism is rarely used within an urban context. Looking at the city of Malaga in southern Spain, they emphasise the importance of integrating tourism activities with other aspects of its economy. A few years later, Hinch $(1996 ; 1998)$ notes that sustainable tourism issues are as important in urban environments as they are in a rural context. He underlines the dynamic nature of urban environments and argues that sustainable tourism strategies in cities "need to be designed to deal with change rather than to suppress it" (Hinch, 1996, p.103).

Savage, Huang, and Chang (2004) explore how the concept of sustainable tourism applies to urban destinations, using the Singapore River thematic zone as a study area. They point out the difficulty in achieving sustainable tourism even on a small scale, "because success in one area may be offset by trade-offs in another" (Savage et al., 2004, p.224). For example, maintaining a clean waterway was obtained at the price of overlooking the socio-cultural aspect of the riverine activity. The authors also highlight the dynamic nature of sustainable tourism, which is considered a continuous process aimed at addressing the issues associated with tourism development in a destination.

Timur and Getz (2008) examine three urban destinations in Canada and the USA, focusing their research on networks and managing stakeholders for sustainable tourism development in cities. Their findings show that the local government together with destination management organisations are perceived to have the greatest power in developing and managing a destination. More recently, Miller et al. (2015) look at pro- 
environmental behaviour within an urban context and analyse the extent to which tourists in Melbourne engage in activities such as recycling and green transport. Maxim (2015) appears to be the only author to focus on sustainable tourism implementation in cities, but the paper is limited in scope, looking only at factors that contribute to a better implementation of sustainable tourism policies in urban areas.

Although there is a healthy literature on sustainable cities (e.g Flint \& Raco, 2012; Joss, 2015; Newman \& Jennings, 2008), this neglects tourism in spite of its importance for the development of many urban destinations. While aspects related to climate change, green space, urban design, transportation, energy, water, waste, safety and security (to name a few) are thoroughly discussed in this literature, tourism is only sporadically mentioned in a few texts as contributing to the economy of cities (Evans, Joas, Sundback, \& Theobald, 2005; Mega, 2010).

\section{Sustainable tourism implementation}

Sustainable tourism implementation is an underresearched area in general (Dodds \& Butler, 2010; Farsari et al., 2011; Liburd \& Edwards, 2010), and even more so in an urban context (Maxim, 2015). Among the first to study this field, Page and Thorn (1997; 2002) examine sustainable tourism planning in New Zealand and focus on the implementation of the Resource Management Act 1991. A later study conducted by Connell, Page, and Bentley (2009) recognises the progress made by the New Zealand government in adopting a national tourism strategy and developing policies to be implemented at local level, but underlines the major gap between the strategy and its implementation. 
Using an evaluative qualitative model proposed by Simpson (2001), Ruhanen $(2004 ; 2008)$ investigates to what extent sustainable development principles are considered in the tourism plans produced by the local government in Queensland, Australia. Both studies note that even though most of the plans include objectives related to sustainable development, the strategic actions mentioned by the majority of these documents do not effectively address this concept. This disparity is attributed by the author to the lack of understanding by policy makers of what sustainability means and how it can be implemented (Ruhanen, 2008).

In a European context, Dodds and Butler (2010) look at barriers that impede the implementation of sustainable tourism polices in two Mediterranean tourist destinations. The study found that even though the research participants were aware of the benefits of sustainable tourism, "the individual advantage from exploiting $[\ldots]$ pooled or shared resources is often perceived as being greater than the potential long-term shared losses that result from the deterioration of such resources" (Dodds \& Butler, 2010, p.35). Consequently, there is little motivation for those involved in tourism management to engage in sustainable tourism development and protect the resources that tourism depends upon. Focusing their work on Cornwall in the UK, Waligo et al. (2013) examine how different stakeholders could be more effectively involved in sustainable tourism implementation. More recently, Muangasame and McKercher (2015) investigate the implementation of the "7 Greens" sustainable tourism policy in Thailand and identify a number of challenges, including the lack of clear objectives and collaboration between different government departments.

A review conducted by the researcher on previous studies that look at sustainable tourism implementation reveals that even though "theoretical and methodological approaches appear to have matured over time” (Ruhanen et al., 2015, 
p.517), not many frameworks or models are available to help examine the implementation of sustainable tourism polices in practice. Soteriou and Coccossis (2010) for example, propose a framework to evaluate the capability of integrating sustainable tourism into the planning system at national level, focusing their work on strategic planning practices in national tourism organisations. In their paper, Waligo et al. (2013) present a Multi-Stakeholder Involvement Management framework to help examine the stakeholder participation in the implementation of sustainable tourism.

When looking at instruments or models used by other authors to examine tourism policy documents in terms of their compliance with sustainable tourism principles, the only one identified is an evaluative qualitative model proposed by Simpson (2001). With some adjustments, the instrument was subsequently used by Ruhanen $(2004 ; 2008)$ to determine the extent to which sustainable development principles were integrated into the planning process in several destinations in

Queensland, Australia. Albeit a useful tool, when the analysis is based solely on tourism planning documents, it is difficult to accurately evaluate the integration of sustainable tourism principles into the planning process using this model. For example, it would be almost impossible to evaluate stakeholder contribution and its influence on the final strategic direction adopted by local authorities (which is one of the criteria of this instrument) based solely on evidence gathered from a tourism plan, a limitation also acknowledged by Ruhanen (2008).

\section{The role of local authorities in sustainable tourism implementation}

Many studies emphasise the important role played by Governments and local authorities in the planning and management of tourism in a destination, in particular in promoting and implementing sustainable tourism policies (Hall, 2008; Ruhanen, 2013; UNEP \& 
WTO, 2005). Local and central government are believed to have a set of advantages in managing the complex phenomenon of tourism due to their competences in a number of related policy areas that influence its development, such as infrastructure, spatial planning, and transport (Mowforth \& Munt, 2009). They have the authority and powers needed to maintain political stability, to provide legal and financial frameworks, security and social infrastructure, all necessary for sustainable tourism development. Furthermore, local authorities are considered to be better placed to perform the "delicate task of juggling private sector interests with local resident needs and wants, in order to maintain the economic health of the community and ensure that development is sustainable" (Jamal \& Getz, 1995, p.193). Although they have been often criticized for being reactive rather than proactive (Ashworth \& Page, 2011), and for limited implementation of sustainability principles (Connell et al., 2009), a recent study concludes that despite their shortcomings "local governments are still best placed to drive the sustainable development agenda within a destination” (Ruhanen, 2013, p.92).

In order to promote sustainable tourism in a destination, local authorities need to adopt policy documents to guide the development of this activity and to integrate sustainable tourism principles into these documents (Hall, 2008; Connell et al., 2009; Bramwell \& Lane, 2010). But as with the definition, different organisations and academics suggest different sets of principles for this concept (Hunter, 1997; McKercher, 2003; Sharpley, 2009; Torres-Delgado \& Saarinen, 2014). A detailed discussion on the different sets of principles proposed so far is beyond the scope of this paper, which is mainly concerned with the implementation phase and the sustainable tourism initiatives promoted by local authorities. Therefore, it will focus solely on one such set deemed by the author most suitable for this research. 
In its "Design Guidelines for Sustainable Tourism Development", the South Australian Tourism Commission (2007) propose a set of 12 sustainable tourism principles. These have been embraced by a number of organisations as they take into consideration the main characteristics of sustainable tourism and link the concept with the three pillars of sustainability (Sharpley, 2009). They are designed to promote mutual benefits to both visitors and local communities, while safeguarding the built and natural environment upon which tourism depends. Although these principles were not created specifically with an urban context in mind, they are aimed at making all forms of tourism more sustainable including tourism in cities (South Australian Tourism Commission, 2007). What makes them particularly relevant for cities is that they look to promote conservation outcomes and authentic attractions with good design that reflect the local history and culture, aspects contributing to the distinctiveness of a destination.

Acknowledging the important role played by local government in the sustainable development of tourism, this paper explores whether local authorities in urban areas have implemented policies towards sustainable tourism. This is achieved through a case study analysis of the initiatives promoted by the local authorities in London towards sustainable development of this activity. This study also looks at whether local authorities in the capital have integrated sustainable tourism principles into the planning documents that guide the development of tourism.

\section{Tourism in London}

London is one of the largest cities in Europe, which accommodates about 15 million international visitors each year (GLA Economics, 2012) and in 2014 was ranked the world's top destination city (Hedrick-Wong \& Choong, 2014). The capital is an 
important gateway for the UK, with three out of four visitors to the country arriving through one of its airports (LDA, 2009). As a result, over a quarter of all tourism expenditure in the country occurs in London (Office for National Statistics, 2014), making this activity the second most important economic sector in the capital after financial services (Maitland \& Newman, 2009b). The city offers a large variety of attractions, with the most famous ones including historic buildings, well-known museums, art galleries, and parks (GLA Economics, 2012).

Despite London being a world tourist destination for many decades, a review of existing literature shows that to date there has been only limited research on tourism development in the capital. Bull and Church $(1996 ; 2001)$ discuss the London tourism complex, while Bull (1997) reviews some of the problems that London needs to address in order to increase visitor numbers. Long (2000) examines a particular case of interorganisational collaboration for local tourism development in the capital, while Evans (2000) presents a critique of tourism policy in London in the context of local environmental plans. Maitland and Newman (2009b) review tourism trends in London focusing on two different areas, Islington and Bankside, while Stevenson and Inskip (2009) investigate how a group of people perceive London as a capital city by looking at photographic images they provided.

More recently, Travis (2011) dedicates a chapter to tourism planning in the UK and focuses his work on tourism in London before 2008. He highlights the problems caused in some inner London boroughs ${ }^{1}$ (i.e. the City of Westminster, Kensington \& Chelsea, and Camden) by the large number of visitors and notes the measures taken to

\footnotetext{
${ }^{1}$ There are 33 local authorities in London, the 32 London boroughs and the City of London. According to the Greater London Authority (GLA, 2011), these are split into 14 inner boroughs - including the City of London, and 19 outer London boroughs.
} 
better spread tourism activities across the capital. Exploring the role of creative industries in the development of tourism in cities, Pappalepore, Maitland, and Smith (2014) focus their work on East London, an area featuring "large concentrations of artists, designer-makers and new media practitioners" (p. 232). Maxim (2015) examines sustainable tourism development in London and identifies a number of drivers of success that could help policy makers in their effort to implement sustainable tourism policies at local level.

In terms of tourism governance in London, the past few years have seen a number of important changes that influenced the planning and management of tourism in the capital. Following the May 2010 elections, a new coalition government was installed, formed by the Conservatives and the Liberal Democrats. The localism agenda, aiming to promote bottom-up driven policies, was a major point in the program of the new government. Thus, in November 2011, the Localism Act was adopted with the intention to shift the power from central government to local authorities and to make them more accountable to the communities they serve (Lowndes \& Pratchett, 2012). This act abolished all regional strategies with the exception of London, the capital being the only place in the UK allowed to maintain its strategic document - the London Plan. Furthermore, as a consequence of the 2008 global financial crisis that prompted deep budget cuts across the UK public sector, the London Development Agency (LDA) - the main organisation responsible for the development of tourism in the capital - was abolished in March 2012.

At national level, considerable changes in the planning system in the UK were brought in by the new National Planning Policy Framework, published in March 2012 (DCLG, 2012). An important change introduced by this document is the presumption in favour of sustainable development, which was welcomed by the business sector but was 
opposed by a number of organisations and members of the public. In terms of guidance for tourism, there is currently no specific planning policy guidance (PPG), as the $P P G$ 21: Tourism was superseded in May 2006 by the Good Practice Guide on Planning for Tourism (DCLG, 2006a). This shows a relaxation of the planning provisions for tourism development, as the guide has more of an advisory role.

In addition, a new tourism strategy for Britain was produced in March 2011 by the Department for Culture, Media and Sport (DCMS, 2011). The major change brought in by this new strategy is the orientation of tourism development towards local level and the private sector, so that it is no longer dependent on public funding. This is in contrast to a number of studies that underline the important role played by local and central Government in planning and managing tourism (Hall, 2008; Ruhanen, 2013), two essential processes for the sustainable development of this activity (Edgell, DelMastro, Smith, \& Swanson, 2008).

At local level, the new London Plan ${ }^{2}$ published by the Greater London Authority ${ }^{3}$ promotes the capital as an international visitor destination and highlights the need to extend the benefits of tourism across the capital in order to reduce the pressure on central London (GLA, 2011). Although the London Plan does not contain any reference to the concept of sustainable tourism, it does mentions that the Mayor "supports a more sustainable approach to the way the tourism industry operates in London" (GLA, 2011, p.125) by reducing $\mathrm{CO}_{2}$ emissions, water use and waste

\footnotetext{
${ }^{2}$ The London Plan is the spatial development strategy for the capital that provides the policy context for the local planning policies of London boroughs.

${ }^{3}$ Greater London Authority (GLA) is the strategic administrative body for Greater London. According to the 1999 Greater London Authority Act, the Mayor is responsible for the promotion and development of tourism in London.
} 
generation. A change of focus from tourism growth towards sustainability and quality in tourism can also be observed in the strategic priorities proposed in the latest London Tourism Vision 2006-2016 (LDA, 2006), when compared against those included in the previous tourism policy document (GLA, 2002). To support the delivery of the ten year vision, two tourism action plans were produced, with the latest focused mainly on capitalising on the 2012 Olympic and Paralympic Games opportunities (LDA, 2009).

Although there is no space to discuss in detail the 2012 Olympic Games and their legacy for London, it should be mentioned that sustainability represented a fundamental element from the bid proposal and carrying on all the way through the games and beyond. In its post-games report "Making a difference", the Commission for Sustainable London 2012 (2013) claimed that these were "the most sustainable Games ever" and that "sustainable practices inspired by London 2012 should out-weigh the inevitable negative impacts of the Games over time" (p. 2). However, when it comes to the Queen Elizabeth Olympic Park, Smith (2014) notes the shift in emphasis and "the move away from the original vision of large parklands and a blueprint for sustainable living" (p. 315) towards a vision focused more on destination making with spectacular attractions and activities able to attract more visitors to East London.

\section{Methodology}

To explore the process of sustainable tourism implementation in an urban setting, this research uses London as an exploratory case study. This method is commonly used when investigating tourism destinations (Altinay \& Paraskevas, 2008; Yin, 2009) as it helps understand complex phenomena by looking at individual examples (Veal, 2011). In support of this method, Gerring (2007) notes that "sometimes, in-depth knowledge 
on an individual example is more helpful" as it contributes to a "better understanding of the whole by focusing on a key part" (p. 1). As seen in the previous section, London is one of the largest cities in Europe attracting vast numbers of visitors, but has been surprisingly neglected as a research subject with respect to sustainable tourism. Yet, the concept of sustainability is widely promoted in its planning policy documents produced by central and local government, making the capital a good case study for researching sustainable tourism implementation in an urban context.

The methodology adopted offers the advantage of using both qualitative and quantitative data, gathered through multiple methods of data collection (i.e. online survey, interviews and document analysis), and enables the author to use the technique of triangulation (Decrop, 2004). This allows for the findings of each investigation to be verified against the others, therefore improving the validity of the research (Veal, 2011). Although single-case studies offer a poor basis for generalisation (Yin, 2009), the merit of this research is that it provides an in-depth understanding of a highly relevant case study context that can help other local authorities in large cities in their efforts to implement sustainable tourism policies.

\section{Secondary data analysis}

Prior to the collection and analysis of primary data, it was deemed important to look at the existing policy documents relevant to the chosen case study (Simons, 2009; Yin, 2009). The tourism policy documents produced by the 33 local authorities in London were therefore examined to see whether they incorporate sustainable tourism principles. This yielded valuable information on a number of aspects that were explored further during the interviews and online questionnaires. 
In the first instance, the London boroughs were contacted and asked to supply copies of any tourism policy documents they had produced in the previous five years. A third of the boroughs responded, but none provided additional information beside what was already available on their websites. The next step was to collect the most recent tourism and visitor policies, strategies or plans from the local authorities' websites. In addition, if they contained references to other policy documents that contribute to the development of tourism in the area, these were also collected and added to the analysis (e.g. cultural, arts or events strategies). Thus, a total of 43 policy documents were found to guide the development of tourism at borough level at the time of the research, and formed the basis for this analysis (see Table 1).

*INSERT TABLE 1 HERE*

A review of existing literature in the field identified a single instrument (Simpson, 2001) that examines whether a tourism planning process in a destination is in conformity with sustainable development principles. As discussed earlier, this instrument is not deemed suitable when the analysis is based only on tourism planning documents. Therefore, to examine whether sustainable tourism principles were integrated into the relevant planning documents, the research proposes a different approach considered more appropriate when taking into account the various types of documents included in the analysis and the different topics they cover.

The first step was to select a set of sustainable tourism principles (the rationale used when selecting these principles is discussed in the literature review section), followed by an evaluation of the policy documents selected for the analysis. This approach provided useful information about the sustainable tourism principles integrated by the local authorities in London into the planning documents guiding tourism development in their area. These findings were then compared against the 
responses received for question 17 of the survey applied to the representatives of the local authorities (Q17. How important is each of the following principles of sustainable tourism for your borough?). The response options included with this question in the survey were the same as the sustainable tourism principles used in the analysis of the policy documents. Therefore, a comparison could be made between the sustainable tourism principles considered important by the representatives of the London boroughs, and the principles that are actually promoted in the planning policy documents produced by their organisation.

The selected documents were then examined using the technique of content analysis, a tool often used to investigate policy issues in tourism (Hall \& Valentin, 2005; Moscardo, 2011; Moyle, McLennan, Ruhanen, \& Weiler, 2014, 2014) and which allowed the researcher to analyse the policy documents in a systematic way (Bryman \& Bell, 2011). A number of concepts and themes were first selected (corresponding to the sustainable tourism principles used in the research) and the documents were then coded manually. This method has certain limitations, such as the subjectivity of the researcher in interpreting the text and the difficulty in understanding why things happen (Bryman \& Bell, 2011). Another limitation is the temporal factor, as only the most recent policy documents publically available at the time of the research $(2011-2012)$ were included in the analysis. To address these limitations and improve the validity of the research findings, the results from secondary data analysis were triangulated with those from primary data collection and analysis (Altinay \& Paraskevas, 2008). More specifically, the questions included in the online survey and the interviews conducted with the representatives of local authorities in London helped validate and complemented the data collected through document analysis. 


\section{Online survey}

The next stage was to conduct an online survey using the SNAP software, targeted at representatives involved in the planning and management of tourism from the 33 local authorities in London. Its aim was to collect primary data in terms of sustainable tourism implementation by local authorities in the capital. To compile the list of possible respondents, an email was sent to the planning departments of each borough asking for the contact details of the person responsible for tourism planning and management. The questionnaires were then sent to these representatives (where such a person existed) or otherwise, to the heads of the planning departments. After two reminders, 31 of the 33 local authorities in London responded to the survey (yielding a satisfactory response rate of $94 \%$ ) and these answers formed the basis of the analysis. The two local authorities that did not complete the online questionnaire (the London Boroughs of Bromley and Haringey) sent email responses stating that tourism is a very small sector in their area and that they do not have any policies towards promoting sustainable tourism. This was surprising for the London Borough of Haringey as it is home to Alexandra Palace, an important attraction considered by the borough itself to be the iconic destination in North London.

In terms of the profile of respondents, over a third of those that completed the questionnaire were heads of departments or units (e.g. planning, spatial strategy, leisure and culture), nearly half were planning officers, and the remaining four were other officers (e.g. economic development, visitor economy).

\section{Semi-structured interviews}

To gather a more in-depth insight on sustainable tourism implementation in the capital, following the survey a number of semi-structured interviews were conducted with 
representatives of public and private organisations involved in tourism development in London. This type of interview combines the flexibility of the unstructured interviews with the comparability offered by including key questions (Veal, 2011). To record the answers as accurately as possible, the interviews were audio-recorded and the responses were later transcribed, coded and analysed. The snowball technique (Altinay \& Paraskevas, 2008) was considered the most suitable sampling tool for selecting the relevant organisations to be included in this stage of the study, as many structural changes were occurring at the time of the research and affecting the main bodies responsible with tourism planning in London. The interviews continued until preliminary analysis of the data revealed saturation and no new information was emerging through additional interviews (Sarantakos, 2005).

A number of large tourism organisations or lobby groups were also contacted for interviews. Their opinion on the sustainable development of tourism in London was deemed relevant at this stage, as besides the public sector, the tourism industry is another important stakeholder in the development of tourism in a destination (Waligo et al., 2013). As a result, a total of 22 interviews were conducted with representatives from four different types of organisations: five local authorities (e.g. Royal Borough of Greenwich, City of Westminster, City of London), seven public-private partnerships (e.g. London \& Partners, South London Partnership, North London Strategic Alliance), five business improvement districts ${ }^{4}$ - BIDs (e.g. Camden Town United, Team London

${ }^{4}$ As stated on the GLA website (2012), “A Business Improvement District is a geographical area within which the businesses have voted to invest collectively in local improvements to improve their trading environment. [...] BIDs provide additional or improved services as identified and requested by local businesses, such as extra safety, cleaning and environmental measures." 
Bridge, Victoria BID), and five tourism or lobbying organisations (e.g. ABTA, The Tourism Alliance, The Travel Foundation). These interviews provided additional qualitative data that helped understand whether different stakeholders consider the sustainable development of tourism in London a priority and what initiatives they promote towards it.

\section{Results - Sustainable tourism implementation in London}

A total of 43 policy documents were found to guide the development of tourism at local level and formed the basis for the analysis, with only 12 of them being tourism or visitor documents (covering about a third of the local authorities in London). Comparing the current data against that from the 1980 s, when $59 \%$ of the boroughs had a specific tourism policy (Evans, 2000), a considerable reduction can be seen in the number of local authorities that produced a dedicated policy document to guide tourism development in their area. Evans (2000) notes that the absence of a tourism policy or plan reflects the non-interventionist stance adopted by most London boroughs towards tourism, which contributes to "the growing concern with the negative environmental and related social impacts of tourism in local economies" (p. 312). The remaining 21 boroughs integrate tourism into other policy documents, most of them being cultural, arts or events strategies. This reaffirms the close relationship between tourism activities in cities and arts and culture, an association that was previously noted by other researchers (Howie, 2003; OECD, 2014; Pappalepore et al., 2014) and encouraged over the years by a number of organisations (DCLG, 2006b; GLA, 2010). 


\section{Understanding and promoting sustainable tourism}

It has been argued that in order to implement measures for sustainable tourism development, policy makers should be aware of this concept and understand its meaning (Ruhanen, 2008). Therefore, the interview respondents (IR) were first asked whether sustainable tourism should be considered a priority for the development of tourism in London and how they would define this concept. The majority of respondents agree that it should be a priority, as stressed by one representative of an inner London borough:

\footnotetext{
"Very much so, London receives a very large number of visitors each year and these visitors have a significant impact on the city's infrastructure. So if there is anything that can be done to minimise that impact is important." (IR no. 5)
}

Yet, a number of respondents note that even though they personally think that sustainable tourism should be a priority, other colleagues from their organisations may not be of the same opinion. One interviewee for example, mentioned that sustainability used to be high on the agenda before the onset of the economic downturn in 2008, but it moved down the list of priorities ever since. Other concerns are now of greater importance on the agenda of their organisations (such as achieving economic growth and tackling unemployment), and thus sustainable tourism "just gets lost amongst other things" (IR no. 12). Another respondent goes further and points out that only to recognize sustainable tourism as a priority is not enough and thus,

\footnotetext{
"The question is would they resource it, make that a particular policy? And I suspect the answer to that is no at the moment." (IR no. 14)
}

In terms of how they would define this term, the research participants (both from interviews and questionnaires) offered very different interpretations, mirroring the variety of definitions proposed by different organisations for this concept. Nevertheless, 
most of them described sustainable tourism as a balance between different aspects, such as economic benefits, a better experience for visitors and protecting the environment, while a few made references to the local communities. The difficulty however lies in finding the right balance between all these factors and interests in order to get to the "sweet spot" - as called by a respondent (IR no. 15), something that requires cooperation between all stakeholders involved in tourism development (Edgell et al., 2008). The majority of research participants however acknowledged the negative consequences that accompany tourism development in a destination and indicated that sustainable tourism is about reducing these impacts.

Looking at which London boroughs promote sustainable tourism in their planning policy documents (based on the answers from the online questionnaire), only a third of local authority representatives indicated that this concept is promoted by their organisation. Among these are seven of the ten London boroughs that have a dedicated unit or team for tourism development (see Figure 1). This indicates that the local authorities with a dedicated unit for tourism are more likely to promote the concept of sustainable tourism in their planning documents. It is worth noting that the three inner London boroughs attracting the majority of London visitors (i.e. Westminster, Kensington \& Chelsea, and Camden) and which should be more concerned with the negative consequences that accompany tourism activities are not among those promoting this concept.

\section{*INSERT FIGURE 1 HERE*}

In terms of political affiliation, no obvious link was found between the political party holding the majority in the local council at the time of the research and the local authorities that had a dedicated unit for tourism, or those which promote sustainable tourism in their planning documents. For instance, sustainable tourism is promoted by 
five of the seventeen Labour boroughs, two of the eleven Conservative boroughs, one of the two Liberal Democrat boroughs, one of the two boroughs with no overall control, and The City of London. This supports the findings of Stevenson, Airey and Miller (2008), who note that in Britain it "is difficult to connect tourism policies with rightist or leftist ideology because ideological considerations do not clearly underpin the actions of government" (p. 737).

In terms of sustainable tourism initiatives, the representatives of only five local authorities in London indicated that they promote such measures. The large majority of survey participants responded that their borough does not have any sustainable tourism initiatives or they do not know of such initiatives. Among the sustainable tourism measures promoted by local authorities are initiatives such as offering free advice to tourism businesses, promoting public transport or other sustainable means of transport, and a programme that aims to facilitate temporary art activities in vacant properties. Beside these initiatives, only a few other measures were identified by the interview respondents (e.g. installing drinking fountains for visitors to refill their water bottles rather than buy new plastic ones; trying to reduce energy and water consumption as well as minimising waste; and encouraging local residents into the tourism industry by advising new tourism developments coming into the area to employ local people). Therefore, they all admitted that at the moment there are not many such activities promoted by their organisations (see Table 2 for a complete list of the sustainable tourism initiatives identified by the research participants).

*INSERT TABLE 2 HERE* 


\section{The integration of sustainable tourism principles}

As noted in relevant literature (Ruhanen, 2004; Connell et al., 2009), to implement sustainable tourism local authorities need to consider the principles which underpin this concept and integrate them into the policy documents that guide tourism development. Therefore, this paper also investigates whether the representatives of the London boroughs that took part in the survey consider important the sustainable tourism principles proposed in this study and whether these are integrated into their planning policy documents. A large majority of respondents indicated that each of these 12 sustainable tourism principles is important for their borough. More specifically, all principles were deemed important by at least half of the survey participants, while 7 of them were seen to be important by over $80 \%$ of the respondents. There is a connection between the principles considered important by most research participants and those included by the majority of local authorities in their planning documents. For example, four of the principles considered important by most respondents are among the five that were integrated by most London boroughs in their policy documents guiding the development of tourism (see Figure 2).

* INSERT FIGURE 2 HERE*

Principle 10 - Enhancing sense of place through design, achieved the best survey result with 30 of the 31 participants indicating it as important. An explanation may be that the majority of survey participants work in the planning departments and design is an important aspect for planners in urban destinations. Principle 9 - Having good content was considered important by almost two thirds of the respondents, while only two local authorities have included it in their tourism policy documents. Another principle surprisingly neglected is related to involving the local communities and 
building local capacity (principle 12), mentioned by only three boroughs in their policy documents.

The only local authority that considers all 12 sustainable tourism principles is the City of London, which has in place a visitor strategy and also makes references to tourism in its cultural strategy. On the other hand, rather surprisingly, the City of Westminster - a borough with many tourist attractions that receives the most visitors does not have a dedicated tourism or visitor strategy to manage this activity, but only a report from 2006 which reviews tourism. This borough includes in its relevant policy documents about half of the principles suggested in this study, mainly those related to protection and conservation, and community involvement. However, Westminster is already a well-known destination; therefore, it is not surprising that principles relating to differentiating from other destinations are overlooked in its policy documents guiding tourism.

Finally, it was observed that the local authorities with a dedicated tourist/visitor strategy or policy to guide the development of tourism were likely to consider more sustainable tourism principles in their policy documents compared to those that do not have such a document but make reference to tourism in other policy documents. This aspect is particularly obvious in outer London, where all 3 boroughs that produced a specific tourism/visitor strategy (i.e. Harrow, Croydon and Bexley) included at least eight of the sustainable tourism principles adopted in this analysis.

\section{Discussion}

The theoretical and methodological approach adopted in this study allowed the collection of in-depth and unique data on urban tourism, which helped better understand 
this complex phenomenon. It provided a holistic view of tourism planning in London and offered the advantage of examining the development of this activity at the local (borough) level. The analysis of data from multiple sources helped identify the particularities as well as the context of sustainable tourism planning in the capital. Understanding the context is important as it provides the setting within which these policies are formulated and can highlight issues and implications for other large cities (Moyle et al., 2014).

An examination of the national and local policy documents that influence tourism planning in London shows that the central government has given local authorities more power to decide what is best for their area. These are encouraged to work in partnership with the private sector in order to attract more funds, so that tourism development in their area is no longer dependent on public funding (DCMS, 2011). However, while local authorities are best placed to manage tourism in a destination (Dodds \& Butler, 2009) and to promote sustainable initiatives (Ruhanen, 2013), not much can be achieved when resources are limited. These changes in the tourism governance were driven top-down by political ideologies and the localism agenda promoted by the central government, rather than by consideration of the specific needs of the tourism industry in the capital (Kennell \& Chaperon, 2013).

At the same time, there has been a significant reduction in the resources allocated by London boroughs for the planning and management of tourism, with only a few local authorities having policies in place to guide this activity. This situation contrasts with studies that highlight the importance of tourism for the economy of the capital (Maitland \& Newman, 2009b; Maxim, 2015), and the recommendations of the Good Practice Guide on Planning for Tourism (DCLG, 2006a). One of the reasons may be the impact of the 2008 financial crisis and the subsequent economic downturn that 
prompted deep budget cuts for the UK public sector as a whole. As a non-statutory function (Stevenson, 2002), tourism was among the first policy areas to loose resources in this difficult economic climate. Still, the UK Government see tourism as "a potential growth sector in the context of the economic crisis, able to capitalise on the weak national currency to attract overseas visitors" (Kennell \& Chaperon, 2013, p.278). Therefore, if London is to take advantage of the benefits of tourism while limiting its negative impacts, local authorities would need to prepare planning policies to help manage this activity (Mason, 2008).

Another explanation may be that local authorities in London view tourism as only one component of a complex system which contributes to building or maintaining system resilience (McCool, 2013). Indeed, world tourism cities such as London are complex environments, where tourism is only one function among many others embedded in the economy of the city (Edwards et al., 2008; Maitland \& Newman, 2009a). Therefore, some boroughs may have decided that other economic activities would be more suitable for the sustainable development of their area. This, for example, appears to be the case for the Borough of Camden, an inner London borough that attracts many visitors and which faces social and environmental issues, but which does not have a dedicated tourism policy document to guide this activity. The borough currently promotes itself as a place for arts and culture, encouraging creative industries in particular. Yet, as stated on the borough's website, Camden remains one of the main visitor destinations in London and most likely will continue to attract many tourists in future. Therefore, ignoring this activity and the negative impacts associated with it could have detrimental consequences for both visitors and local community.

Yet, even though sustainable development is considered a core principle for tourism planning in the UK, there is only limited guidance to help local authorities 
implement this concept in practice. The tendency to promote strategic guidance rather than regulations for tourism planning is noted by Bramwell and Lane (2010), who argue that effective management systems for sustainable tourism "are, however, likely to require intervention and regulation by the state" (p. 1). This is further emphasised by Buckley (2012), who underlines that self-regulation is ineffective when trying to improve the social and environmental performance of the tourism industry.

This study reveals that most policy makers in London believe that sustainable tourism should be a priority and recognise the importance of implementing its principles, but only a few local authorities in the capital promote these principles and even fewer have in place initiatives to put them in practice. As seen in the previous sections, most of these initiatives are isolated activities which address only limited aspects of sustainable tourism. There is thus a discrepancy between the holistic approach that sustainable tourism implies (Choi \& Sirakaya, 2006; Farsari et al., 2011) and the simplistic measures implemented by some London boroughs. Hence, it appears that in practice there has not been much progress towards achieving sustainable development of tourism in the capital, and the statement made by Testoni (2001) more than ten years ago is still applicable to London even today - "Sustainable tourism is accepted as being desirable but there is often a gap between policy endorsement and policy implementation" (p. 198).

\section{Conclusion}

This paper focused on understanding the current situation in terms of the development and implementation of sustainable tourism policies in cities, using London as an exploratory case study. As Elliott (2006) underlines, cities are "central to attempts at 
meeting the goals of sustainable development in the sense that this is where the majority of world's population will soon be located, with all the associated physical demands [...] and the political, social and cultural requirements associated with the adoption of urban values" (p. 191). Large cities are complex environments that perform a variety of functions and important tourist destinations which attract many visitors. Therefore, the investigation of sustainable tourism implementation in such environments is an important topic that to date has received very limited consideration. Although the results are based on the findings of a single case study, a number of the issues raised may have implication for other urban destinations, and in particular for other large cities.

This study has found that sustainability is at the core of the UK government policy agenda (at least rhetorically) and that policy makers in London consider important the implementation of sustainable tourism principles in practice. Yet, only a small number of local authorities have integrated these principles into their plans and strategies guiding tourism development in their area. Furthermore, just a few local authorities have put in place initiatives for sustainable tourism, most of which are simplistic and isolated measures that only address limited aspects of sustainable tourism. These findings concur with the results of other studies (Dodds \& Butler, 2009; Ruhanen, 2013; Sharpley, 2009) which stress that the implementation of sustainable tourism by policy makers is very limited in practice.

Reflecting on these findings, they present a challenge for sustainable tourism development in London, and the reasons why this picture has emerged needs further thought. Tourism is only one activity among the various industries that form the economy of an urban destination, particularly in world tourism cities such as London, and therefore may struggle to attract the resources required for its planning and management (two processes recognised as vital for the sustainable development of this 
activity). To address this, there is a need for strong political will that would help local and central government to commit the necessary financial and human resources to manage this activity (Dodds \& Butler, 2009). This however is problematic in the current economic climate that has brought important structural changes and budget cuts for the main organisations responsible for tourism development in London. As a non-statutory function for local authorities, tourism was among the first remits to loose resources.

Furthermore, similar to other recent studies (Ruhanen, 2013; Yüksel et al., 2012), it was observed that economic growth and development remain the primary objectives of governments and local authorities, while social and environmental issues are often left behind. Although the process of implementing social and environmental measures is more difficult and requires commitment and cooperation at multiple levels, these are essential aspects in progressing towards sustainable development of tourism in a destination, and thus limiting the negative impacts that accompany this activity.

Further research is needed to fully understand the implications of the aforementioned structural changes and the reduction in governmental oversight and support for the tourism industry, and how these might influence the sustainable development of this activity. At the same time, it would be interesting to see whether such changes can be found in other large urban destinations, or if this situation is specific to London. The future direction of tourism development in the UK seems to be cooperation and working in partnership, which is strongly encouraged in the latest tourism strategy for Britain (DCMS, 2011). Therefore, another topic for future research would be to explore the reasons why local authorities do, or do not choose to collaborate with other organisations (e.g. political will, attracting more resources, conflicts to be overcome), what benefits they expect out of these partnerships, and what results such partnerships have had so far. 


\section{Acknowledgement}

The author would like to thank Prof Graeme Evans and Dr Jo Foord for their valuable insights and the three anonymous reviewers for their valuable comments. 


\section{References}

Altinay, L., \& Paraskevas, A. (2008). Planning research in hospitality and tourism. Oxford: Elsevier.

Ashworth, G. J. (1989). Urban tourism: An imbalance in attention. In C. P. Cooper (Ed.), Progress in tourism, recreation and hospitality research (pp. 33-54). London: Belhaven.

Ashworth, G. J., \& Page, S. J. (2011). Urban tourism research: Recent progress and current paradoxes. Tourism Management, 32(1), 1-15.

Barke, M., \& Newton, M. (1995). Promoting sustainable tourism in an urban context: Recent developments in Malaga city, Andalusia. Journal of Sustainable Tourism, 3(3), 115-134.

Bramwell, B., \& Lane, B. (2010). Sustainable tourism and the evolving roles of government planning. Journal of Sustainable Tourism, 18(1), 1-5.

Bramwell, B., \& Lane, B. (2014). The 'critical turn' and its implications for sustainable tourism research. Journal of Sustainable Tourism, 22 (1), 1-8.

Bryman, A., \& Bell, E. (2011). Business research methods (3rd ed.). New York: Oxford University Press.

Buckley, R. (2012). Sustainable tourism: Research and reality. Annals of Tourism Research, 39(2), 528-546.

Bull, P. (1997). Tourism in London: Policy changes and planning problems. Regional Studies, 31(1), 82-85.

Bull, P., \& Church, A. (1996). The London tourism complex. In: C. M. Law (Ed.), Tourism in major cities (pp. 155-178). London: International Thomson Business Press.

Bull, P., \& Church, A. (2001). Understanding urban tourism: London in the early 1990s. International Journal of Tourism Research, 3(2), 141-150.

Butler, R. (2013). Sustainable tourism - the undefinable and unachievable pursued by the unrealistic? Tourism Recreation Research, 38(2), 221-226.

Choi, H.C., \& Sirakaya, E. (2006). Sustainability indicators for managing community tourism. Tourism Management, 27(6), 1274-1289.

Commission for a Sustainable London 2012. (2013). Making a Difference. Retrieved from: http://www.cslondon.org/wp-content/uploads/downloads/2013/03/CSLMaking-a-Difference-2013.pdf. 
Connell, J., \& Page, S. J. (2008). The evolution and development of sustainable tourism: Progress and prospects. In S. J. Page \& J. Connell (Eds.), Sustainable tourism: Critical concept in the social sciences (pp.1-20). London: Routledge.

Connell, J., Page, S. J., \& Bentley, T. (2009). Towards sustainable tourism planning in New Zealand: Monitoring local government planning under the Resource Management Act. Tourism Management, 30(6), 867-877.

DCLG. (2006a). Good practice guide on planning for tourism. London: DCLG.

DCLG. (2006b). Regeneration through culture, sport and tourism. Retrieved from DCLG website: http://www.communities.gov.uk/archived/publications/ localgovernment/regenerationthroughculture

DCLG. (2012). National Planning Policy Framework. Retrieved from DCLG website: http://www.environment-agency.gov.uk/static/documents/Business/ NPPF_published_27Mar2012.pdf

DCMS. (2011). Government Tourism Policy. Retrieved from DCMS website: http://www.culture.gov.uk/images/publications/Government2_Tourism_Policy_ 2011.pdf

Decrop, A. (2004). Trustworthiness in qualitative tourism research. In: J. Phillimore. \& L. Goodson (Eds.), Qualitative research in tourism: Ontologies, epistemologies and methodologies (pp. 156-169). London: Routledge.

Dodds, R., \& Butler, R. W. (2009). Inaction more than action: Barriers to the implementation of sustainable tourism policies. In S. Gössling, C. M. Hall, \& D. Weaver (Eds.), Sustainable tourism futures: Perspectives on systems, restructuring and innovations (pp. 44-57). Abingdon: Routledge.

Dodds, R., \& Butler, R. W. (2010). Barriers to implementing sustainable tourism policy in mass tourism destinations. Tourismos: An International Multidisciplinary Journal of Tourism, 5(1), 35-53.

Edgell, D.L., DelMastro, A.M., Smith, G., \& Swanson, J. (2008). Tourism Policy and Planning: Yesterday, Today and Tomorrow. Oxford: Butterworth-Heinemann.

Edwards, D., Griffin, T., \& Hayllar, B. (2008). Urban tourism research: Developing an agenda. Annals of Tourism Research, 35(4), 1032-1052.

Elliott, J.A. (2006). An introduction to sustainable development (3rd ed.). Routledge. European Communities. (2000). Towards quality urban tourism: Integrated quality management (IQM) of urban tourist destinations. Retrieved from EC website: 
http://ec.europa.eu/enterprise/sectors/tourism/files/studies/towards_quality_touri sm_rural_urban_coastal/iqm_urban_en.pdf

Evans, B., Joas, M., Sundback, S., \& Theobald, K. (2005). Governing sustainable cities. London: Routledge.

Evans, G. (2000). Planning for urban tourism: A critique of borough development plans and tourism policy in London. International Journal of Tourism Research, 2(5), $307-326$.

Farsari, I., Butler, R.W., \& Szivas, E. (2011). Complexity in tourism policies: A cognitive mapping approach. Annals of Tourism Research, 38(3), 1110-1134.

Flint, J., \& Raco, M. (2012). The future of sustainable cities: Critical reflections. Bristol: Policy Press

Gerring, J. (2007). Case study research: Principles and practices. New York: Cambridge University Press.

GLA (2002). Visit London: the Mayor's Plan for Tourism in London. Retrieved from the GLA website: http://legacy.london.gov.uk/gla/publications/visit_london/report.pdf.

GLA. (2010). Cultural Metropolis: The Mayor's Cultural Strategy - 2012 and Beyond. Retrieved from the GLA website:

http://www.london.gov.uk/sites/default/files/CulturalMetropolis.pdf

GLA. (2011). The London plan: Spatial development strategy for Greater London.

Retrieved from the GLA website:

http://www.london.gov.uk/sites/default/files/The\%20London\%20Plan\%202011. pdf

GLA Economics. (2012). Tourism in London (Working Paper No. 53). Retrieved from: http://www.london.gov.uk/sites/default/files/wp53.pdf

Hall, C. M. (2008). Tourism planning: Policies, processes and relationships (2nd ed.). Harlow: Pearson Education.

Hall, C.M. (2011). Policy learning and policy failure in sustainable tourism governance: From first- and second-order to third-order change? Journal of Sustainable Tourism, 19(4-5), 649-671.

Hall, C.M., \& Valentin, A. (2005). Content Analysis. In: B. W. Ritchie, P. Burns, \& C. Palmer (Eds.), Tourism Research Methods: Integrating Theory with Practice (pp.191-209). Wallingford: CABI Publishing. 
Hedrick-Wong, Y., \& Choong, D. (2014). MasterCard 2014 Global Destination Cities Index. MasterCard Worldwide Insights. Retrieved from: http://newsroom.mastercard.com/wpcontent/uploads/2014/07/Mastercard_GDCI_2014_Letter_Final_70814.pdf

Hinch, T.D. (1996). Urban tourism: Perspectives on sustainability. Journal of Sustainable Tourism, 4(2), 95-110.

Hinch, T. D. (1998). Sustainable urban tourism attractions: The case of Fort Edmonton Park. In C. M. Hall \& A. A. Lew (Eds.), Sustainable tourism: A geographical perspective (pp. 185-198). Harlow: Longman.

Howie, F. (2003). Managing the tourist destination. London: Thompson Learning.

Hunter, C. (1997). Sustainable tourism as an adaptive paradigm. Annals of Tourism Research, 24(4), 850-867.

Jamal, T.B., \& Getz, D. (1995). Collaboration theory and community tourism planning. Annals of Tourism Research, 22(1), 186-204.

Joss, S. (2015). Sustainable cities: Governing for urban innovation. New York: Palgrave Macmillan.

Kennell, J., \& Chaperon, S. (2013). Analysis of the UK Government's 2011 tourism policy. Cultural Trends, 22(3-4), 278-284.

Krutwaysho, O., \& Bramwell, B. (2010). Tourism policy implementation and society. Annals of Tourism Research, 37(3), 670-691.

Law, C. M. (2002). Urban tourism: The visitor economy and the growth of large cities (2nd ed.). London: Continuum.

LDA. (2006). London Tourism Vision 2006-16, London: London Development Agency.

LDA. (2009.) London Tourism Action Plan 2009-13. Retrieved from the LDA website: http://www.lda.gov.uk/Documents/London_Tourism_Action_Plan_200913_6537.pdf

Liburd, J. J., \& Edwards, D. (2010). The future of sustainability. In J. J. Liburd \& D. Edwards (Eds.), Understanding the sustainable development of tourism (pp. 225-237). Oxford: Goodfellow.

Long, P. (2000). Development regimes in the city fringe: The case of Discover Islington, London. Journal of Sustainable Tourism, 8(3), 190-206. 
Lowndes, V., \& Pratchett, L. (2012). Local governance under the coalition government: Austerity, localism and the 'Big Society'. Local Government Studies, 38(1), 2140.

Maitland, R., \& Newman, P. (2009a). Developing world tourism cities. In R. Maitland \& P. Newman (Eds.), World tourism cities: Developing tourism off the beaten track. (pp. 1-21). New York: Routledge.

Maitland, R., \& Newman, P. (2009b). London: tourism moving east? In R. Maitland \& P. Newman (Eds.), World tourism cities: Developing tourism off the beaten track (pp. 66-86). New York: Routledge.

Mason, P. (2008). Tourism impacts, planning and management (2nd ed.). Oxford: Elsevier.

Maxim, C. (2015). Drivers of success in implementing sustainable tourism policies in urban areas. Tourism Planning and Development, 12(1), 37-47.

McCool, S. (2013). Sustainable tourism: Guiding fiction, social trap or path to resilience? Tourism Recreation Research, 38(2), 214-221.

McKercher, B. (2003). Sustainable tourism development - Guiding principles for planning and management, Paper presented at the National Seminar on Sustainable Tourism Development, Bishkek, Kyrgyzstan.

Mega, V.P. (2010). Sustainable cities for the third millennium: The odyssey of urban excellence. New York: Springer.

Miller, D., Merrilees, B., \& Coghlan, A. (2015). Sustainable urban tourism: understanding and developing visitor pro-environmental behaviours. Journal of Sustainable Tourism, 23(1), 26-46.

Moscardo, G. (2011). Exploring social representations of tourism planning: issues for governance. Journal of Sustainable Tourism, 19(4-5), 423-436.

Mowforth, M., \& Munt, I. (2009). Tourism and sustainability: Development, globalization and new tourism in the third world (3rd ed.). New York: Routledge.

Moyle, B.D., McLennan, C.J., Ruhanen, L., \& Weiler, B. (2014). Tracking the concept of sustainability in Australian tourism policy and planning documents. Journal of Sustainable Tourism, 22(7), 1037-1051. 
Muangasame, K., \& McKercher, B. (2015). The challenge of implementing sustainable tourism policy: a 360-degree assessment of Thailand's '7 Greens sustainable tourism policy'. Journal of Sustainable Tourism, 23(4), 497-516.

Newman, P., \& Jennings, I. (2008). Cities as sustainable ecosystems: Principles and practices. Washington, D.C: Island Press.

OECD. (2014). Tourism and the creative economy. OECD Publishing. Retrieved from OECD website: http://dx.doi.org/10.1787/9789264207875-en

Office for National Statistics. (2014). The regional value of tourism 2011. Retrieved from ONS website: http://www.ons.gov.uk/ons/dcp171776_353069.pdf

Page, S. J., \& Thorn, K. (1997). Towards sustainable tourism planning in New Zealand: Public sector planning responses. Journal of Sustainable Tourism, 5(1), 59-77.

Page, S. J., \& Thorn, K. (2002). Towards sustainable tourism development and planning in New Zealand: The public sector response revisited. In S. J. Page \& J. Connell (Eds.) (2008), Sustainable tourism: Critical concept in the social sciences (pp. 76-95). London: Routledge.

Pappalepore, I., Maitland, R., \& Smith, A. (2014). Prosuming creative urban areas. Evidence from East London. Annals of Tourism Research, 44, 227-240.

Robinson, J. (2004). Squaring the circle? Some thoughts on the idea of sustainable development. In S. J. Page \& J. Connell (Eds.), (2008) Sustainable tourism: Critical concept in the social sciences (pp. 151-175). London: Routledge.

Ruhanen, L. (2004). Strategic planning for local tourism destinations: An analysis of tourism plans. Tourism and Hospitality Planning \& Development, 1(3), 239253.

Ruhanen, L. (2008). Progressing the sustainability debate: A knowledge management approach to sustainable tourism planning. Current Issues in Tourism, 11(5), $429-455$.

Ruhanen, L. (2013). Local government: Facilitator or inhibitor of sustainable tourism development? Journal of Sustainable Tourism, 21(1), 80-98.

Ruhanen, L., Weiler, B., Moyle, B.D., \& McLennan, C.J. (2015). Trends and patterns in sustainable tourism research: a 25-year bibliometric analysis. Journal of Sustainable Tourism, 23(4), 517-535.

Sarantakos, S. (2005). Social research (3rd ed.). New York: Palgrave Macmillan. 
Savage, V.R., Huang, S., \& Chang, T.C. (2004). The Singapore River thematic zone: Sustainable tourism in an urban context. The Geographical Journal, 170(3), $212-225$.

Sharpley, R. (2009). Tourism development and the environment: Beyond sustainability?. London: Earthscan.

Simons, H. (2009). Case Study Research in Practice. London: Sage Publications Ltd.

Simpson, K. (2001). Strategic planning and community involvement as contributors to sustainable tourism development. Current Issues in Tourism, 4(1), 3-41.

Smith, A. (2014). From green park to theme park? Evolving legacy visions for London's Olympic Park. Architectural Research Quarterly, 18(4), 315-323.

Soteriou, E.C., \& Coccossis, H. (2010). Integrating Sustainability into the Strategic Planning of National Tourism Organizations. Journal of Travel Research, 49(2), $191-205$.

South Australian Tourism Commission. (2007). Design guidelines for sustainable tourism development. Adelaide: SATC.

Stevenson, N. (2002). The role of English local authorities in tourism. Tourism Insights, 13.

Stevenson, N., Airey, D., \& Miller, G. (2008). Tourism Policy Making: The Policymakers' Perspectives. Annals of Tourism Research, 35(3), 732-750.

Stevenson, N., \& Inskip, C. (2009). Seeing the sites: Perceptions of London. In R. Maitland \& B. W. Ritchie (Eds.), City tourism: National capital perspectives (pp. 94-109). Wallingford: CABI.

Testoni, L. (2001). Planning for sustainable tourism. Pacific Tourism Review, 4, 191199.

Timur, S., \& Getz, D. (2008). A network perspective on managing stakeholders for sustainable urban tourism. International Journal of Contemporary Hospitality Management, 20(4), 445-461.

Torres-Delgado, A., \& Saarinen, J. (2014). Using indicators to assess sustainable tourism development: a review. Tourism Geographies, 16(1), 31-47.

Travis, A.S. (2011). Planning for tourism, leisure and sustainability: International case studies. Wallingford: CABI.

UNEP, \& WTO. (2005). Making tourism more sustainable: A guide for policy makers. Paris: UNEP/WTO. 
Veal, A.J. (2011). Research methods for leisure and tourism: A practical guide (4th ed.). Harlow: Prentice Hall.

Waligo, V.M., Clarke, J., \& Hawkins, R. (2013). Implementing sustainable tourism: A multi-stakeholder involvement management framework. Tourism Management, 36, 342-353.

Yin, R. K. (2009). Case study research: Design and methods (4th ed.). London: Sage.

Yüksel, A., Yüksel, F., \& Culha, O. (2012). Ministers' statements: A policy implementation instrument for sustainable tourism? Journal of Sustainable Tourism, 20(4), 513-532. 
Table 1. Policy documents that guide the development of tourism at the borough level

\begin{tabular}{|c|c|}
\hline London boroughs & Policy documents (collected between 2011 and 2012) \\
\hline Barking \& Dagenham & - no policy document \\
\hline Barnet & - no policy document \\
\hline Bexley & $\begin{array}{l}\text { Visitor Strategy (2005) / Cultural Strategy 2003-2008 / } \\
\text { Arts Strategy 2008-2013 }\end{array}$ \\
\hline Brent & Tourism in Brent (2007) / Cultural Strategy 2010-2015 \\
\hline Bromley & Cultural Strategy 2007-2012 \\
\hline Camden & $\begin{array}{l}\text { Creative \& Cultural Industries (2009) / Camden Town Place } \\
\text { Plan (2010) }\end{array}$ \\
\hline City of London & Visitor Strategy 2010-2013 / Cultural Strategy 2010-2014 \\
\hline Croydon & $\begin{array}{l}\text { Tourism Strategy 2005-2008 / Culture \& Sport Strategy 2009- } \\
2012\end{array}$ \\
\hline Ealing & Cultural Strategy 2007-2012 \\
\hline Enfield & $\begin{array}{l}\text { Cultural Strategy 2005-2008 / Arts \& Creativity Strategy 2009- } \\
2013\end{array}$ \\
\hline Greenwich & Tourism Strategy 2004-2010 \\
\hline Hackney & Cultural Policy Framework (2005) \\
\hline $\begin{array}{l}\text { Hammersmith \& } \\
\text { Fulham }\end{array}$ & $\begin{array}{l}\text { Visitor Development Action Plan 2007-2009 / Events Strategy } \\
\text { 2009-2012 }\end{array}$ \\
\hline Haringey & Cultural Strategy \& Action Plan (2008) \\
\hline Harrow & Tourism Strategy \& Action Plan 2009-2012 \\
\hline Havering & Arts Strategy 2007 - 2012 / Cultural Strategy 2012-2014 \\
\hline Hillingdon & Tourism Study (2007) \\
\hline Hounslow & - no policy document \\
\hline Islington & Cultural Strategy 2010-2015 \\
\hline Kensington \& Chelsea & Visitor Policy 2009-2020 \\
\hline Kingston & Cultural Strategy 2008-2012 \\
\hline Lambeth & Developing a Cultural Strategy (2010) \\
\hline Lewisham & Cultural Strategy 2009-2012 / Arts Strategy 2009 \\
\hline Merton & Cultural Strategy 2007-2010 \\
\hline Newham & $\begin{array}{l}\text { Sustainable Community Strategy 2010-2030 / Leisure, Tourism } \\
\& \text { Sport (2006) }\end{array}$ \\
\hline Redbridge & Arts Development and Events Unit Strategy 2008-2012 \\
\hline Richmond & Cultural Service Strategic Plan 2007-2012 \\
\hline Southwark & Tourism strategy 2005 - 2010 / Outdoor Events Policy (2011) \\
\hline Sutton & Arts Strategy 2007-2010 \\
\hline Tower Hamlets & Cultural Strategy (2007) \& Action Plan 2007-2010 \\
\hline Waltham Forest & Culture Strategy 2010-2030 \\
\hline Wandsworth & Cultural Strategy 2009-2014 \\
\hline Westminster & $\begin{array}{l}\text { Review of Tourism (2006) / Strategy for Arts and Culture 2008- } \\
2013 \text { \& Action Plan 2008-2011 }\end{array}$ \\
\hline
\end{tabular}


Table 2. Sustainable tourism initiatives

\begin{tabular}{|c|c|c|c|c|c|c|}
\hline \multirow[t]{2}{*}{ Sustainable Tourism Initiative } & \multicolumn{4}{|c|}{$\begin{array}{c}\text { Type of } \\
\text { organisation }\end{array}$} & \multicolumn{2}{|c|}{$\begin{array}{c}\text { Data } \\
\text { source }\end{array}$} \\
\hline & LA & TO & PPP & BID & OS & I \\
\hline $\begin{array}{l}\text { Art in Empty Spaces Programme - art projects in empty shop units } \\
\text { to bring them back to life }\end{array}$ & $\mathrm{x}$ & & & & $\mathrm{X}$ & \\
\hline Free Business advice to tourism businesses & $\mathrm{x}$ & & & $\mathrm{x}$ & $\mathrm{X}$ & \\
\hline Maintain a visitor web page & $\mathrm{x}$ & & & & $\mathrm{X}$ & \\
\hline A campaign for local residents aimed at the VFR market & $\mathrm{x}$ & & & & $\mathrm{X}$ & \\
\hline $\begin{array}{l}\text { Encourage sustainable forms of transport, e.g. public transport and } \\
\text { cycling }\end{array}$ & $\mathrm{x}$ & & $\mathrm{x}$ & & $\mathrm{x}$ & $\mathrm{X}$ \\
\hline Use of environmental friendly products & $\mathrm{x}$ & & & & $\mathrm{x}$ & \\
\hline Awards, winning campaigns (e.g. Mayor's Business Awards) & $\mathrm{x}$ & & & & $\mathrm{X}$ & \\
\hline $\begin{array}{l}\text { Promoting the Green Tourism Business Scheme (the national } \\
\text { sustainable tourism certificate) }\end{array}$ & $\mathrm{x}$ & & $\mathrm{X}$ & $\mathrm{x}$ & $\mathrm{x}$ & $\mathrm{X}$ \\
\hline Reducing energy, water and waste / Recycling & $\mathrm{x}$ & $\mathrm{x}$ & $\mathrm{X}$ & $\mathrm{x}$ & & $\mathrm{X}$ \\
\hline $\begin{array}{l}\text { Guidance and education on sustainable tourism (e.g. seminars, } \\
\text { workshops, sharing best practices) }\end{array}$ & $\mathrm{x}$ & $\mathrm{x}$ & & & & $\mathrm{X}$ \\
\hline Standards (e.g. Travel Life) & & $\mathrm{x}$ & & & & $\mathrm{X}$ \\
\hline Info-bike service (mobile tourism information units) & & & & $\mathrm{x}$ & & $\mathrm{X}$ \\
\hline $\begin{array}{l}\text { 'What's on' app - pointing the phone at an attraction, you find out } \\
\text { what events are on that day }\end{array}$ & & & & $\mathrm{x}$ & & $\mathrm{X}$ \\
\hline $\begin{array}{l}\text { Reinvigorating the high streets, providing low cost space for start- } \\
\text { up businesses in creative industries }\end{array}$ & & & & $\mathrm{x}$ & & $\mathrm{X}$ \\
\hline $\begin{array}{l}\text { Introducing bylaws to fine coaches which keep their engines } \\
\text { running while standing to wait for tourists }\end{array}$ & $\mathrm{x}$ & & & & & $\mathrm{X}$ \\
\hline $\begin{array}{l}\text { 'Legible London' - a pedestrian system located in busy areas which } \\
\text { helps visitors finding their way around the city }\end{array}$ & & & $\mathrm{X}$ & & & $\mathrm{X}$ \\
\hline Installing drinking fountains so visitors can refill their water bottles & $\mathrm{X}$ & & & & & $\mathrm{X}$ \\
\hline $\begin{array}{l}\text { Running accommodation schemes to make sure that the B\&B units } \\
\text { are fit for purpose }\end{array}$ & $\mathrm{x}$ & & & $\mathrm{x}$ & & $\mathrm{X}$ \\
\hline $\begin{array}{l}\text { Encouraging local residents into the tourism industry by } \\
\text { recommending to the new tourism developments coming into the } \\
\text { area to employ local people }\end{array}$ & $\mathrm{x}$ & & & & & $\mathrm{X}$ \\
\hline Promoting venues that have in place sustainable policies & & & $\mathrm{x}$ & & & $\mathrm{X}$ \\
\hline $\begin{array}{l}\text { Trying to spread the visitor across other part of London (i.e. 'Go } \\
\text { South Go' project) }\end{array}$ & & & $\mathrm{X}$ & & & $\mathrm{X}$ \\
\hline
\end{tabular}

Note: Abbreviations include: LA - local authority; TO - tourism organisation; PPP - public private partnership; OS - online survey; I - interview. 